\title{
Bioactive Olivacine Derivatives-Potential Application in Cancer Therapy
}

\author{
Beata Tylińska ${ }^{1, *(\mathbb{D})}$ and Benita Wiatrak ${ }^{2} \mathbb{D}$ \\ 1 Department of Organic Chemistry, Faculty of Pharmacy, Wroclaw Medical University, 50-556 Wroclaw, Poland \\ 2 Department of Pharmacology, Faculty of Medicine, Wroclaw Medical University, 50-345 Wroclaw, Poland; \\ benita.wiatrak@umed.wroc.pl \\ * Correspondence: beata.tylinska@umed.wroc.pl
}

Citation: Tylińska, B.; Wiatrak, B. Bioactive Olivacine Derivatives-Potential Application in Cancer Therapy. Biology 2021, 10, 564. https://doi.org/10.3390/

biology10060564

Academic Editor: Armand Keating

Received: 31 May 2021

Accepted: 15 June 2021

Published: 21 June 2021

Publisher's Note: MDPI stays neutral with regard to jurisdictional claims in published maps and institutional affiliations.

Copyright: (c) 2021 by the authors. Licensee MDPI, Basel, Switzerland. This article is an open access article distributed under the terms and conditions of the Creative Commons Attribution (CC BY) license (https:/ / creativecommons.org/licenses/by/ $4.0 /)$.
Simple Summary: Olivacine is a compound isolated from the bark of Aspidosperma olivaceum (a tree found mainly in Southeastern Brazil) that shows multidirectional biological activity. The most important of them is the antiproliferative effect, important in anticancer therapy. This article reviews the literature on the results of research on olivacine and its derivatives carried out in cell laboratories, in preclinical studies in animals and clinical trials in humans. The described activities of these compounds were discussed by comparing the differences in their structure. The most important finding of this review is that some olivacine derivatives exhibit greater anticancer activity than doxorubicin (a commonly used anticancer drug).

Abstract: Olivacine and its derivatives are characterized by multidirectional biological activity. Noteworthy is their antiproliferative effect related to various mechanisms, such as inhibition of growth factors, enzymes, kinases and others. The activity of these compounds was tested on cell lines of various tumors. In most publications, the most active olivacine derivatives exceeded the effects of doxorubicin (a commonly used anticancer drug), so in the future, they may become the main new anticancer drugs. In this publication, we present the groups of the most active olivacine derivatives obtained. In this work, the in vitro and in vivo activity of olivacine and its most active derivatives are presented. We describe olivacine derivatives that have been in clinical trials. We conducted a structure-activity relationship (SAR) analysis that may be used to obtain new olivacine derivatives with better properties than the available anticancer drugs.

Keywords: olivacine; pyridocarbazole; cytostatic; S16020; antitumor; in vitro; in vivo

\section{Introduction}

Pyridocarbazole derivatives, which are alkaloids, have become of interest to many scientists due to their biological activity. The two alkaloids, olivacine and its ellipticine isomer [1,2], showed marked antitumor activity [3,4]. Many laboratories worldwide are trying to modify the structure of the heterocyclic system of pyridocarbazole to obtain analogs with a better therapeutic index. Numerous publications on the subject indicate that the introduction of substituents at the C-1, N-2, C-9, C-11 positions of the pyrido[4,3- $b$ ]carbazole system will play a significant role in the pharmacological activity of the derivatives of the alkaloids in question. In vitro studies have shown that hydroxylation of the C-9 position of various ellipticine and olivacine derivatives increases cytostatic activity over the 9-methoxy derivatives, caused by a greater affinity of the compound for DNA-increased stabilization of the DNA-topo II complex. The mechanism of action and antitumor properties of olivacine are similar to ellipticine and are considered DNA intercalation and topoisomerase II inhibition [5-10]. The cytotoxic effect of ellipticine is also related to the impact on the p53 protein [11,12]. Ellipticine is covalently inserted into the DNA on the metabolic side by cytochrome P450 or peroxidase isoforms [13-21]. It should be emphasized that some olivacine derivatives, such as the compound S16020, showed a broad spectrum of antitumor 
activity and greater activity compared to the ellipticine derivatives and doxorubicin [22-25]. The mechanism of olivacine and ellipticine action is similar, but more publications concern ellipticine, which exhibits greater cytotoxicity than olivacine. However, research shows that olivacine derivatives are less toxic to normal NHDF cells (normal human dermal fibroblasts) than doxorubicin and ellipticine [26,27]. At the same time, it was observed that olivacine derivatives had a stronger effect on the p53 protein (one of the most important suppressors of tumor transformation) level than ellipticine. This article presents reports on olivacine and the most active olivacine derivatives (tested in vitro and in vivo). Structureactivity relationship (SAR) analysis may be used to obtain new olivacine derivatives with better properties than the available anticancer drugs.

\section{Olivacine}

Olivacine $\mathbf{1}$ (1,5-dimethyl-6H-pyrido[4,3-b]carbazole) (guatambuinine) (Figure 1) is an alkaloid and was isolated for the first time from the bark of Aspidosperma olivaceum [2] -a tree found in Southeastern Brazil, Argentina, Paraguay and Bolivia [28]. Aspidosperma olivaceum is a photophilous deciduous tree, reaching a height of $25 \mathrm{~m}$ and a trunk diameter of $90 \mathrm{~cm}$, with white flowers and fleshy fruit (drupe) [29]. Plants of the Aspidosperma order have traditionally been used in Brazilian diagnostics to combat fever and other ailments. The receptors behind these plants' pharmacological action-anti-inflammatory, analgesic, antibacterial—are primarily opposed by monoterpene indole alkaloids. Anti-malarial extracts from these vegetation sources, traditionally obtained from bark decoctions, are used in folk medicine during malaria [30].

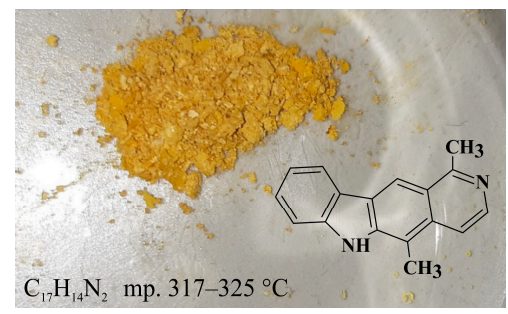

Figure 1. Olivacine (guatambuinine).

A. olivaceum exhibits the anti-malarial effect on quinine-sensitive and quinine-resistant clones of $P$. falciparum, reaching an $\mathrm{IC}_{50}$ value below $10 \mu \mathrm{g} / \mathrm{mL}$ [31]. Olivacine inhibits the growth of $P$. falciparum in vitro $\left(\mathrm{IC}_{50}=1.2 \mu \mathrm{M}\right)$. Noteworthy is the lack of toxic effects of olivacine even in administering high doses (up to $100 \mathrm{mg} / \mathrm{kg} /$ day) [32]. Research by Touaty and Simon shows that olivacine affects the growth of E. coli. In vivo tests indicate that low levels of olivacine have a much stronger effect on the inhibition of protein synthesis in E. coli bacteria than on DNA and RNA synthesis [33]. The interest in olivacine was due to the discovery in 1966 of its anticancer properties. The antitumor activity of olivacine prompted the development of new syntheses to prepare this alkaloid, as a large amount of the compound was needed for further biological tests [3]. To date, more than twenty methods of synthesizing olivacine have been described [34].

Olivacine derivatives that showed better anticancer activity have also begun to be synthesized. There are many possible ways to modify the olivacine structure by extending the side chain at positions $\mathrm{C}-1, \mathrm{~N}-5$, and C-9 and changing the elements in the pyridocarbazole skeleton.

\section{The Most Active Olivacine Derivatives}

\subsection{Structure-Activity Relationship (SAR) Analysis In Vitro}

Structure-activity relationships are based on the discovery that the biological and physicochemical activity of chemical compounds depends on the structure of molecules. Due to this discovery, it can be expected that modification of molecules (replacement of one substituent with another, reduction or enlargement of the molecule) may result in compounds showing better activity or selectivity or will be characterized by better pharmacokinetics. 
After reviewing the literature, we chose the most active olivacine derivatives described in Table 1. We compared compounds that were tested for in vitro cytotoxic activity $\left(\mathrm{IC}_{50} \mu \mathrm{M} \pm \mathrm{SD}\right.$ ) on mouse leukemia (cell line L1210), non-small-cell lung cancer (cell line A549), and breast cancer (cell line MCF-7) cells. We can see how the anticancer activity changes, thereby analyzing olivacine derivative structures using the SAR method (Figure 2).

From the literature studies listed in Table 1, we can see that the cytotoxicity of olivacine $1 \mathrm{IC}_{50}$ against L1210 tumor cells (murine leukemia) is $2.03 \mu \mathrm{M}$. At compound 3, where the carbon at $\mathrm{C}-3$ has been replaced with a nitrogen atom, the antitumor activity is comparable, $\mathrm{IC}_{50}=1.79 \mu \mathrm{M}$ (L1210), $\mathrm{IC}_{50}=4.5 \mu \mathrm{M}$ (MCF-7), to olivacine 1 activity. By introducing a hydroxyl moiety at the C-9 position of olivacine 1 , the activity increases to $\mathrm{IC}_{50}=0.06 \mu \mathrm{M}$ (L1210) for 9-hydroxyolivacine 2. Based on Table 1, which describes the most active olivacine derivatives synthesized and described in the literature, it can be stated that the hydroxyl group significantly increases the antitumor activity because as many as $\mathbf{1 7}$ derivatives out of $\mathbf{2 9}$ described in Table 1 have this grouping. There is also a methoxy moiety (six compounds) at the C-9 position. However, it is this group that lowers the activity. Compound 4 (pazellipticine) has nitrogen deposited in place of carbon C-9; its activity is comparable to that of 9-hydroxyolivacine $\mathbf{2}$, but here an increase in activity can be expected after introducing the ((diethylamino)propyl)amine moiety at the C-1 position. The importance of the hydroxyl group in the C-9 position can be seen in the activity of compounds 6 and 7. Both compounds have a ((diethylamino)propyl)amino substituent in the C-1 position, differing only in structure with the substituent in C-9. Compound 6 has a hydroxyl group and IC50 $=0.02 \mu \mathrm{M}$ (L1210) activity, and compound 7 has a hydroxyl group at the C-9 position and activity of $\mathrm{IC}_{50}=1 \mu \mathrm{M}$ (L1210). The best antitumor activity was shown by compound 9 , known in the literature as S16020, $\mathrm{IC}_{50}=0.0041 \mu \mathrm{M}(\mathrm{L} 1210)$, $\mathrm{IC}_{50}=0.030 \mu \mathrm{M}$ (A549), $\mathrm{IC}_{50}=0.075 \mu \mathrm{M}$ (MCF-7). This relationship has been demonstrated in clinical trials. Because its activity was exceptional, its derivatives were synthesized. Compound 8, known in the literature as S30972-1, was obtained, with $\mathrm{IC}_{50}=0.019 \mu \mathrm{M}$ against L1210. Its structure differs from S16020 with a substituent at position C-9. Instead of a hydroxyl group at the C-9 position, it has pentanedioic acid; its $\mathrm{IC}_{50}=0.019 \mu \mathrm{M}$ against L1210 and is one order lower than S16020. Compound $\mathbf{1 1}$ was also obtained, a methylcarbamoyloxymethyl substituent in the C-9 position and an $\mathrm{IC}_{50}=1.25 \mu \mathrm{M}$ against A549. It can be seen that replacing the hydroxyl group at the C-9 position with another group reduces the antitumor activity. S16020 derivatives were also obtained, which had a phenyl introduced between the pyrido[4,3-b]calbazole moiety in the C-1 position and the ((dimethylamino)ethyl)carbamoyl moiety. Compound 19 has $\mathrm{IC}_{50}=7.15 \mu \mathrm{M}$ against L1210, $\mathrm{IC}_{50}=8.19 \mu \mathrm{M}$ against $\mathrm{A} 549$, and compound 20 has IC $50=6.08 \mu \mathrm{M}$ (L1210), $\mathrm{IC}_{50}=8.25 \mu \mathrm{M}$ (A549). It can be seen that the introduction of phenol caused a decrease in anticancer activity. Also introduced in this position was pyridine (compound No 23) $\mathrm{IC}_{50}=0.05 \mu \mathrm{M}$ (L12010), $\mathrm{IC}_{50}=0.095 \mu \mathrm{M}$ (A549), $\mathrm{IC}_{50}=0.23 \mu \mathrm{M}$ (MCF-7), whose activity turned out to be very interesting. Compounds were also synthesized, which in the C-9 position of the pyrido[4,3-b]carbazole had a hydroxyl group, and in the C-1 position had pyridine, but no ((dimethylamino)ethyl)carbamoyl group; activity for compound $24, \mathrm{IC}_{50}=0.9 \mu \mathrm{M}$ (L1210), $\mathrm{IC}_{50}=5.03 \mu \mathrm{M}$ (A549), and for compound 26, $\mathrm{IC}_{50}=0.8 \mu \mathrm{M}$ (L1210), shows a decrease in biological activity here. $\mathrm{S} 16020$ has also been modified to introduce nitrogen in place of carbon at the C-2 and C-4 positions. For compound 15, $\mathrm{IC}_{50}=0.010 \mu \mathrm{M}$ (L1210). Nitrogen was introduced into compound 16 at the C-1 and C-4 positions, and the ((dimethylamino)ethyl)carbamoyl moiety was placed at the C-2 position. The activity for compound 16 was $\mathrm{IC}_{50}=0.33 \mu \mathrm{M}$ (L1210). Cytotoxicity turned out to be very interesting, especially for compound 15. Among the most active olivacine derivatives described in Table 1, as many as 21 have a methyl group in the C-6 position, and one compound, No. 25, has in the C-6 position dimethylaminoethyl, with $\mathrm{IC}_{50}=1.5 \mu \mathrm{M}$ (L1210), $\mathrm{IC}_{50}=2.12 \mu \mathrm{M}$ (A549). Compound 24, comparable to compound 25, having a methyl substituent in the C-6 position, has $\mathrm{IC}_{50}=0.9 \mu \mathrm{M}$ (L1210), $\mathrm{IC}_{50}=5.03 \mu \mathrm{M}$, (A549). 
Table 1. In vitro and in vivo biological activity of compounds.

\begin{tabular}{|c|c|c|c|c|c|c|c|c|}
\hline \multirow{2}{*}{ No. } & \multirow{2}{*}{ Compound } & \multirow{2}{*}{ Structure } & \multicolumn{3}{|c|}{$\begin{array}{c}\text { In Vitro } \\
\text { Cell Lines } \\
\mathrm{IC}_{50} \mu \mathrm{M} \pm \mathrm{SD}\end{array}$} & \multicolumn{2}{|c|}{ In Vivo } & \multirow{2}{*}{$\begin{array}{c}\text { Reference } \\
\text { Number }\end{array}$} \\
\hline & & & L1210 & A549 & MCF-7 & $\begin{array}{c}\text { Dose } \\
\mathrm{mg} / \mathrm{kg} \\
\text { (Cell Lines) }\end{array}$ & Therapeutic Effect \% & \\
\hline 1 & $\begin{array}{l}\text { 1,5-dimethyl- } 6 \mathrm{H} \text {-pyrido }[4,3-b] \text { carbazole } \\
\text { olivacine }\end{array}$ & & 2.03 & & & $\begin{array}{c}250 \\
(\mathrm{~L} 2110) \\
84.0 \\
(\mathrm{~L} 1220)\end{array}$ & $\begin{array}{c}35 \\
\text { (ILS) } \\
141(\mathrm{~T} / \mathrm{C})\end{array}$ & $\begin{array}{l}{[35]} \\
{[3]}\end{array}$ \\
\hline 2 & $\begin{array}{l}\text { 9-hydroxy-1,5-dimethyl-6H-pyrido[4,3- } \\
\text { b]carbazole } \\
\text { 9-hydroxyolivacine }\end{array}$ & & 0.06 & & & & & [35] \\
\hline 3 & $\begin{array}{l}\text { 1,5-dimethyl-6H-pyridazino }[4,3- \\
\text { b]carbazole }\end{array}$ & & 1.79 & & 4.50 & & & [24] \\
\hline 4 & $\begin{array}{c}\text { 10-\{[3-(diethylamino)propyl]amino\}-6- } \\
\left.\text { methyl-5H-pyrido[3' } 4^{\prime}: 4,5\right] \text { pyrrolo[2,3- } \\
\text { g]isoquinoline } \\
\text { Pazellipticine (PZN) }\end{array}$ & & 0.02 & & & $\begin{array}{c}20 \\
(\mathrm{~L} 1210)\end{array}$ & $\begin{array}{c}85 \\
\text { (ILS) }\end{array}$ & [36] \\
\hline 5 & $\begin{array}{c}\text { 1-\{[3-(diethylamino)propyl]amino\}-9- } \\
\text { methoxy-5-methyl-6H-pyrido[4,3- } \\
\text { b]carbazole }\end{array}$ & & 5 & & & $\begin{array}{c}15 \\
(\mathrm{~L} 1210)\end{array}$ & $\begin{array}{l}24.6 \\
\text { (ILS) }\end{array}$ & [36] \\
\hline
\end{tabular}


Table 1. Cont

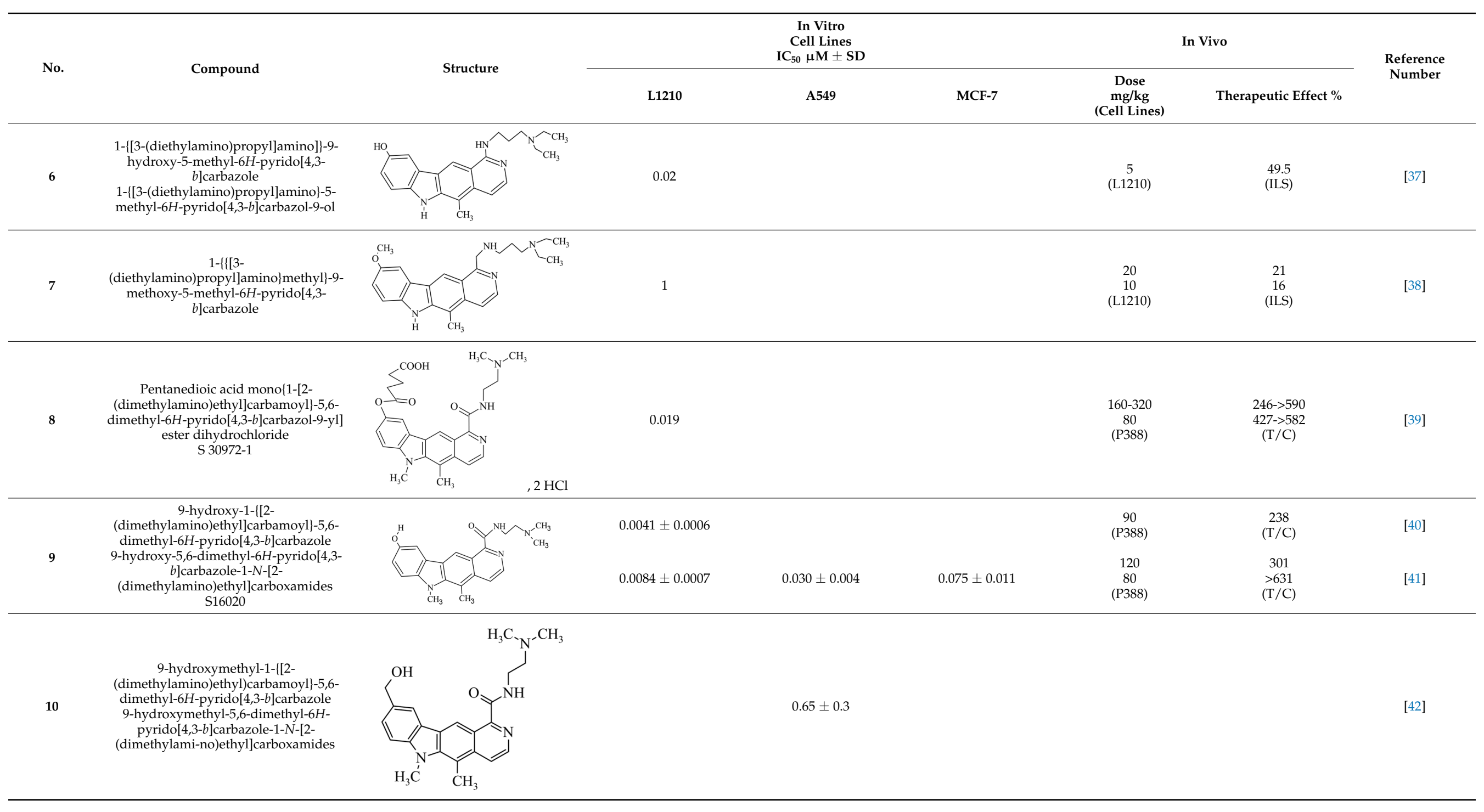


Table 1. Cont.

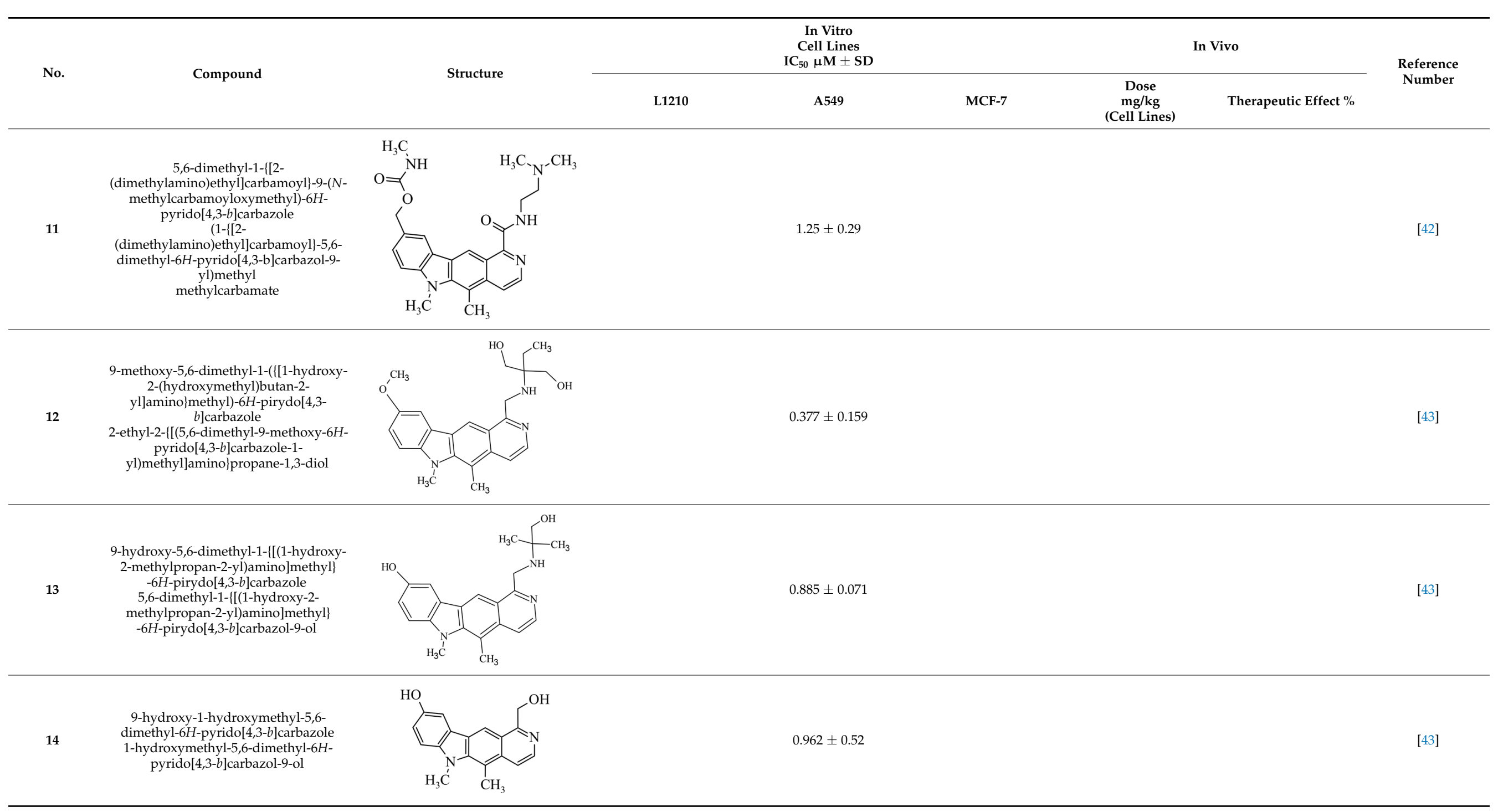


Table 1. Cont.

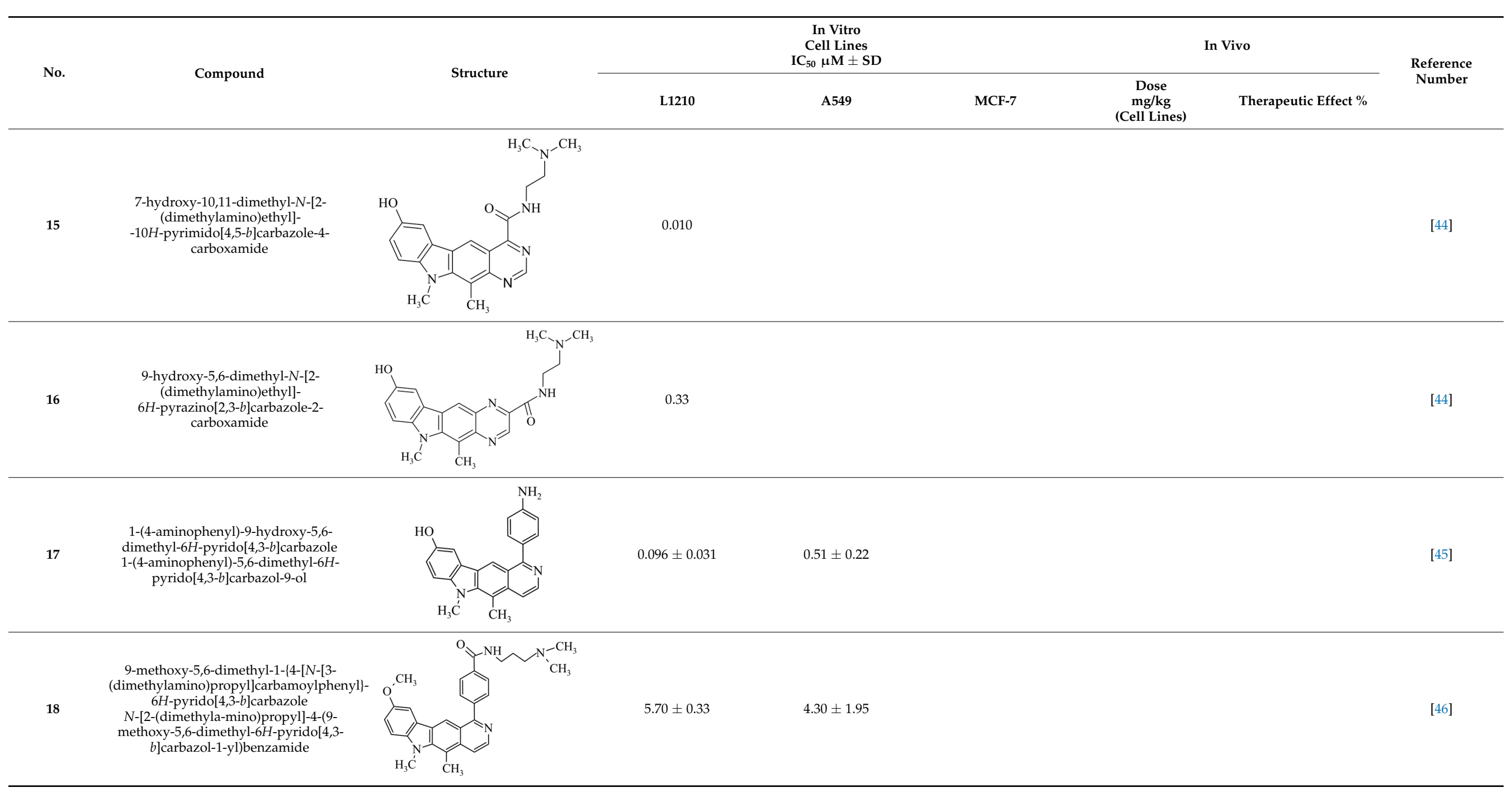


Table 1. Cont.

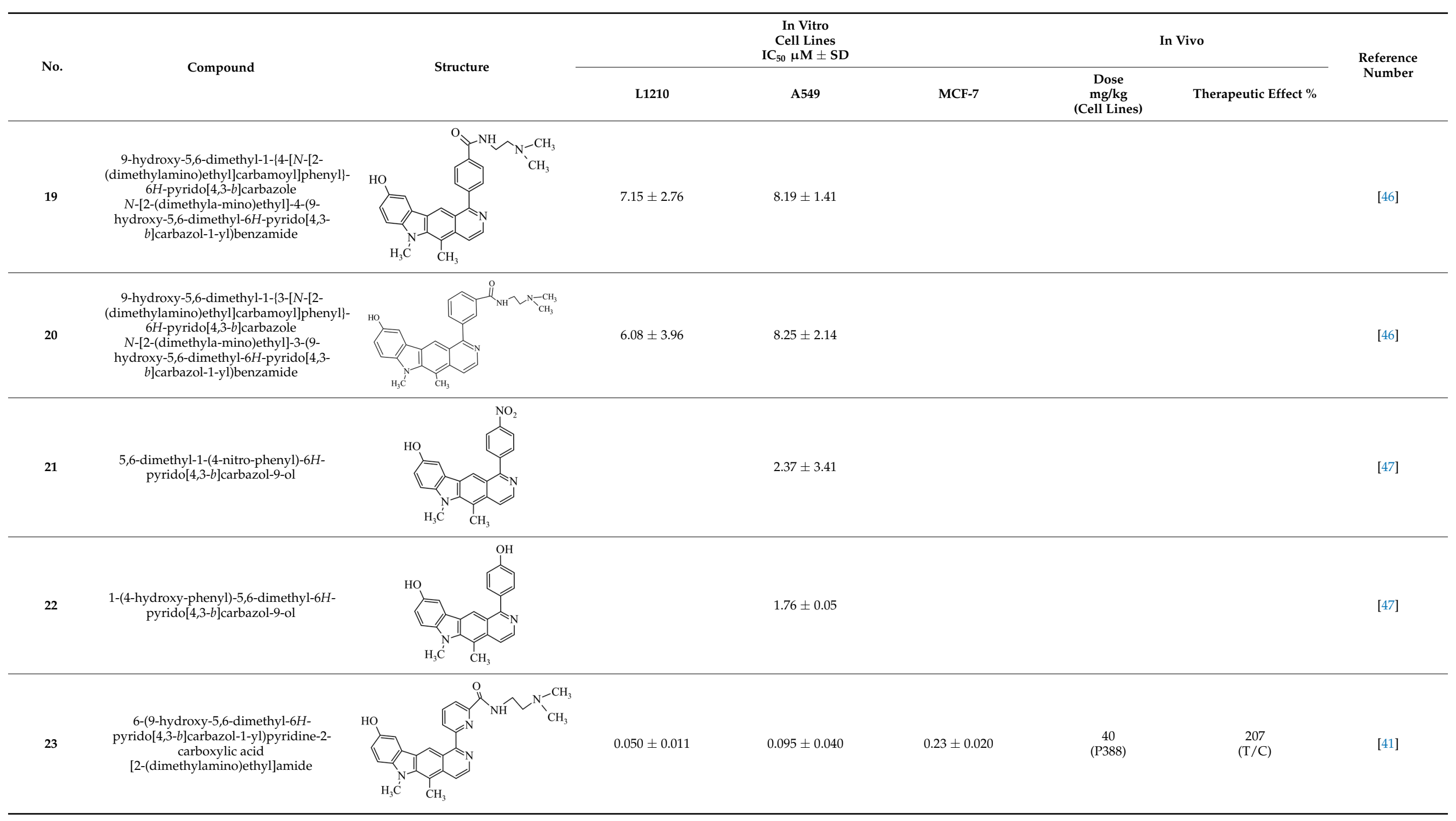


Table 1. Cont.

\begin{tabular}{|c|c|c|c|c|c|c|c|c|}
\hline \multirow{2}{*}{ No. } & \multirow{2}{*}{ Compound } & \multirow{2}{*}{ Structure } & \multicolumn{3}{|c|}{$\begin{array}{c}\text { In Vitro } \\
\text { Cell Lines } \\
\mathrm{IC}_{50} \mu \mathrm{M} \pm \mathrm{SD}\end{array}$} & \multicolumn{2}{|c|}{ In Vivo } & \multirow{2}{*}{$\begin{array}{l}\text { Reference } \\
\text { Number }\end{array}$} \\
\hline & & & L1210 & A549 & MCF-7 & $\begin{array}{c}\text { Dose } \\
\mathrm{mg} / \mathrm{kg} \\
\text { (Cell Lines) }\end{array}$ & Therapeutic Effect \% & \\
\hline 24 & $\begin{array}{c}\text { 5,6-dimethyl-1-(6-methyl-pyridin-2-yl)- } \\
\text { 6H-pyrido[4,3-b]carbazol-9-ol }\end{array}$ & & 0.9 & 5.03 & & & & [42] \\
\hline 25 & $\begin{array}{l}\text { 5-methyl-6-(2-dimethylamino-ethyl)-1- } \\
\text { (6-methyl-pyridin-2-yl)-6H-pyrido[4,3- } \\
\text { b]carbazol-9-ol }\end{array}$ & & 1.50 & 2.12 & & & & [48] \\
\hline 26 & $\begin{array}{c}\text { 5,6-dimethyl-1-(2-methyl-pyridin-4-yl)- } \\
\text { 6H-pyrido[4,3-b]carbazol-9-ol }\end{array}$ & & 0.8 & & & & & [49] \\
\hline 27 & $\begin{array}{l}\text { 5,6-dimethyl-1-(6-methyl-pyridin-3-yl)- } \\
\text { 6H-pyrido[4,3-b]carbazol-9-ol }\end{array}$ & & 0.85 & & & & & {$[50]$} \\
\hline 28 & $\begin{array}{l}\text { 9-methoxy-5,6-dimethyl-1-(1-methyl-4- } \\
\text { nitro-3H-imidazol-5-yl)-6H-pyrido[4,3- } \\
\quad b] \text { carbazole }\end{array}$ & & & $\begin{array}{c}4.74 \pm 1.30 \\
\text { (hypoxic } 0.57 \pm 0.033 \text { ) }\end{array}$ & $\begin{array}{c}5.96 \pm 1.10 \\
\text { (hypoxic } 0.69 \pm 0.053 \text { ) }\end{array}$ & & & [51] \\
\hline 29 & $\begin{array}{l}\text { 9-methoxy-5,6-dimethyl-1-(1-methyl-4- } \\
\text { nitro-2H-pyrazol-5-yl)-6H-pyrido[4,3- } \\
\text { b]carbazole }\end{array}$ & & & $\begin{array}{l}30.50 \pm 5.05 \\
\text { (hypoxic } \\
0.65 \pm 0.019)\end{array}$ & $\begin{array}{c}11.25 \pm 3.42 \\
\text { (hypoxic } 0.81 \pm 0.045 \text { ) }\end{array}$ & & & [51] \\
\hline
\end{tabular}




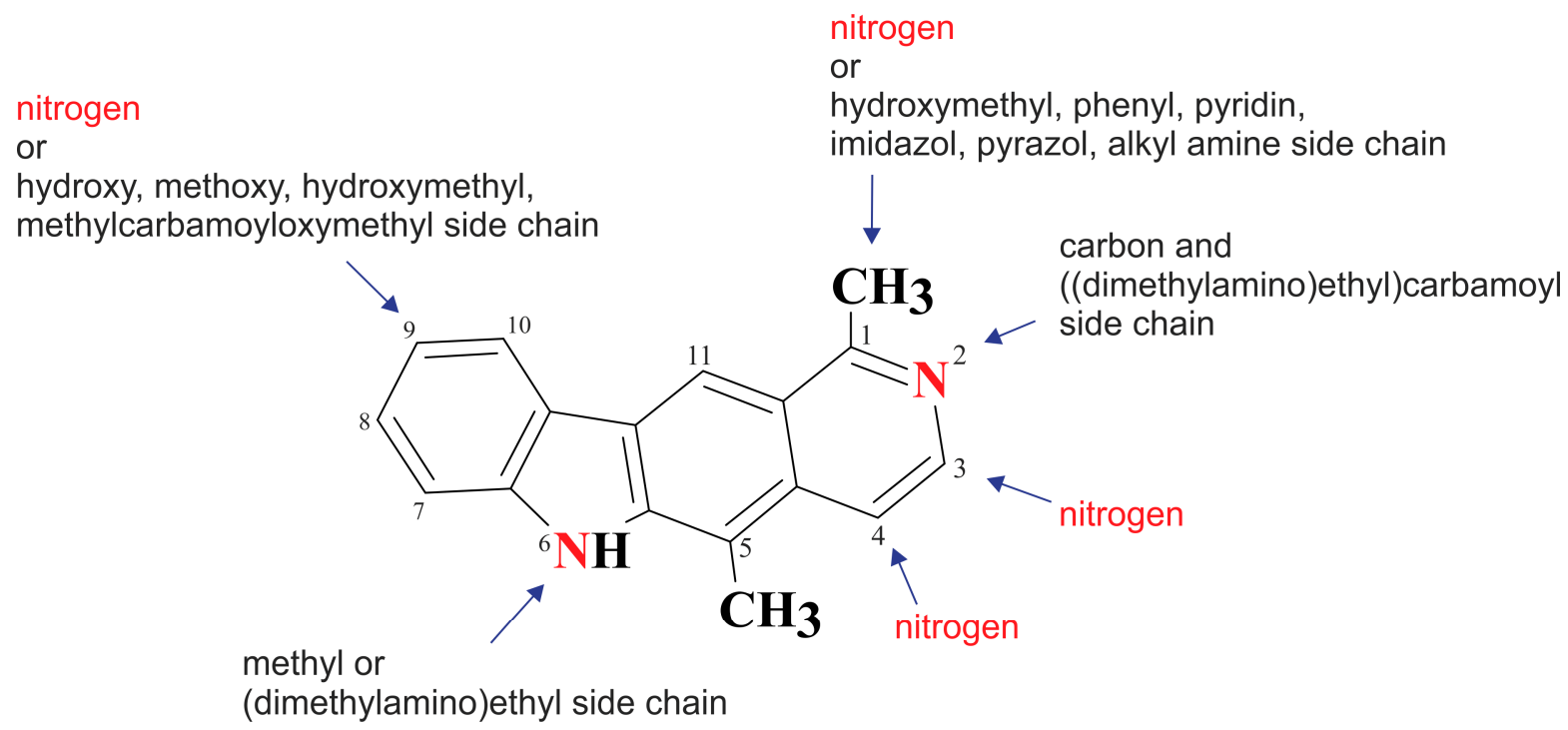

Figure 2. Modification of the structure of olivacine.

Of interest are compounds 28 and 29, which have 4-nitro-imidazole (compound 28) and 4-nitro-pyrazole (compound 29) at the C-1 position. The compounds were tested for antitumor activity under aerobic and anaerobic conditions. For compound 28 in normoxic conditions $\mathrm{IC}_{50}=4.74 \mu \mathrm{M}(\mathrm{A} 549), \mathrm{IC}_{50}=5.96 \mu \mathrm{M}$ (MCF-7) and in hypoxic conditions $\mathrm{IC}_{50}=0.57 \mu \mathrm{M}(\mathrm{A} 549), \mathrm{IC}_{50}=0.69 \mu \mathrm{M}(\mathrm{MCF}-7)$. For derivative 29 in normoxic conditions $\mathrm{IC}_{50}=30.5 \mu \mathrm{M},(\mathrm{A} 549), \mathrm{IC}_{50}=11.25 \mu \mathrm{M}$ (MCF-7) and in hypoxic conditions $\mathrm{IC}_{50}=0.65 \mu \mathrm{M}$ (A549), $\mathrm{IC}_{50}=0.81 \mu \mathrm{M}$ (MCF-7). Compounds 28 and 29 seem to be very interesting because some cancers develop in anaerobic conditions, and there is a need for compounds that will selectively affect cancer tumors.

\subsubsection{9-Hydroxyolivacine 2}

U. Schmidt et al. presented the synthesis and biological studies of olivacine derivatives [52]. They described 8-hydroxyolivacine, 9-hydroxyolivacine and 8-methoxyolivacine and 9-methoxyolivacine. The compounds were tested for growth inhibition of Mycobacterium tuberculosis. 9-methoxyolivacine showed significant inhibition, MIC90 = $1.5 \mu \mathrm{M}$ and olivacine, MIC90 $=4.7 \mu \mathrm{M}$, which shows that olivacine and its derivatives have antitumor activity and show wider bioactivity. The authors rightly note that olivacine's pharmacological potential and its derivatives are much less studied than that of ellipticine and its derivatives [52].

\subsubsection{Azo-Olivacine Derivatives 4, 15, 16}

Olivacine was modified by introducing nitrogen atoms into the pyrido[4,3- $b]$ carbazole system instead of carbon atoms. They showed various anticancer effects.

Pazelliptine 4 (PZE) is a 9-aza derivative of olivacine [36], which exhibits greater antitumor activity and is less toxic than ellipticine [53]. Unlike C-9 ellipticine derivatives, which can be oxidized at the C-10 position and form harmful free radicals capable of alkylating proteins or nucleic acids, N-9 derivatives do not undergo such transformations. They are probably metabolized by oxidation of the nitrogen atom at the N-6 position [54]. Moreover, it seems that ESA is not active against DNA in isolated cell nuclei, probably due to the rapid metabolism of this compound [55].

3-Aza-olivia influenced cancer cells of the cervix (KB), lymphocytic leukemia (L-1210), ovary (SK-OV-3) and breast (MCF-7) only at a relatively high concentration of $3.16 \mu \mathrm{g} / \mathrm{mL}$. In contrast, at lower concentrations, no dose-dependent effect was observed [56]. It seems that such a modification is not the best. 
Studies on other S16020 9 derivatives have shown that the cytotoxicity is influenced not only by the number of nitrogen atoms but also by the location. The pyrazinocarbazole derivative $\mathbf{1 6}$ has been found to exhibit weak cytotoxicity to tumor cells, while derivative 15 has similar cytotoxicity against L1210 murine leukemia cells and P388 leukemia to the parent compound S16020 9 [44].

\subsection{SAR In Vivo}

The in vivo evaluation of olivacine and its derivatives was performed on two experimental mouse models, L12010 leukemia and P388 leukemia. The therapeutic effect of drugs was measured as the percent increase in life span (\% ILS) over controls, evaluated as follows: \% ILS $=$ (median survival time $(\mathrm{MST})$ in treated $)-($ median survival time in controls) $/$ (median survival time in controls $) \times 100$ or $\% \mathrm{~T} / \mathrm{C}=$ median survival time of treated/median survival time of control animals. From the data presented in Table 1, we can see that administering olivacine 1 to diseased mice at a dose of $250 \mathrm{mg} / \mathrm{kg}$ increased their survival by 35\% (ILS), at a dose of $84 \mathrm{mg} / \mathrm{kg} 141 \%$ (T/C). Modifying the olivacine structure and replacing carbon at $9-\mathrm{C}$ with nitrogen, and introducing a diethylaminopropylamine group at C-1 (compound 4) resulted in an increase in survival to $85 \%$ (ILS) at a lower dose of $20 \mathrm{mg} / \mathrm{kg}$. Compound 5 has such an alkylamino chain in the 1-position and the methoxy group in the 9-position at a dose of $15 \mathrm{mg} / \mathrm{kg}, 24 \%$ (ILS). Changing the moiety to hydroxyl at position 9 in compound 6 resulted in a dose reduction of $5 \mathrm{mg} / \mathrm{kg}$ and increased survival to $49.5 \%$. Extending the alkyl chain and introducing a new $\mathrm{CH}_{2}$ group reduced the activity of compound 7 (20 mg/kg, 21\% (ILS), $10 \mathrm{mg} / \mathrm{kg}, 16 \%$ (ILS)) compared to the very similar compound 5. Compound 8 showed the best activity at doses of $160-320 \mathrm{mg} / \mathrm{kg}, 246->590 \%$ (T/C), 80 mg/kg, 427->582\% (T/C). 1-((2-dimethylamino)ethyl)carbamoyl)-5,6-dimethyl9-hydroxy-6H-pyrido[4,3-b]carbazole (S16020) 9 dose $90 \mathrm{mg} / \mathrm{kg}, 238 \%$ (T/C), $120 \mathrm{mg} / \mathrm{kg}$ $301 \%$ (T/C). After introducing the [(dimethylamino)ethyl]pyridine substituent in position 1 of the pyridocarbazole system, compound 23 was obtained, which at a dose of $40 \mathrm{mg} / \mathrm{kg}$ showed a therapeutic effect of $207 \%$ (T/C).

\subsection{Clinical Trials}

So far, the following ellipticine derivatives have been used in clinical trials: celiptium [57-59], datelliptium [60,61], retelliptine [61,62], elliprabin [61] and olivacine derivative: S16020 [25].

So far, the most active synthesized olivacine derivative is 9-hydroxy-5,6-dimethyl-1(2-(dimethylamino)ethyl)carbamoyl)-6H-pyrido[4,3- $b$ ]carbazole 9, known in the literature as S16020. It is an olivacine derivative containing a (2-(dimethylamino)ethyl)carbamoyl moiety in the C-1 position. In the N-6 position, it has a methyl group that blocks the pyrrole nitrogen atom and prevents oxidation of the 9-hydroxy group to the quinoid system responsible for the toxicity of the compound [63]. The derivative of pyrido[4,3-b]carbazole 9 showed significant activity in preclinical studies against the murine leukemia P388, melanoma B16, sarcoma M5076 and human colon C38 and breast cancer cells, ovary and lung $[23,25,40,56,64-68]$. Thanks to its activity comparable to cyclophosphamide [66] and doxorubicin $[64,67]$ and relatively low toxicity, it was qualified for clinical trials $[56,68]$. S16020 was synthesized by R. Jasztold-Howorko, who published the synthesis and biological research of this compound in 1994 [40]. The compound has obtained patent protection in European countries, Japan, and the United States and has been subjected to clinical trials [56,69]. Unfortunately, the compound was not approved for further research. It turned out that, although the average survival time of patients treated with S16020 was slightly longer than that of patients treated with methotrexate, facial and tumor swelling as well as erythematous rash prevented the inclusion of the new olivacine derivative in the next phase of clinical trials [70]. However, only this derivative of olivacine has been so thoroughly researched, and it is the subject of the largest number of articles.

As a result of arylation of S16020 9 with glutaric anhydride, the new compound S30972-1 8 was obtained, which turned out to be more active in vivo and less toxic than 
doxorubicin and etoposide [71]. The study found that combination 8 is presumably a prodrug of S16020 9 [72].

\subsection{Influence on the Effectiveness of Radiotherapy}

The derivative $\mathrm{S} 16020$ has also been studied in conjunction with radiation therapy. Combining ionizing radiation with intercalators [73] and inhibitors of topoisomerase II [22] often leads to an increase in its toxicity. This was demonstrated in studies using the HEP2 human tumor line and mice, comparing the effects of ionizing radiation in combination with S16020. Differences in the activity of topoisomerase II in tissues (a higher expression of topoisomerase II characterizes tumor cells compared to normal cells) cause the S16020 compound used alone to increase the cytotoxic effect of radiation during ionization, without increasing its toxicity to healthy tissues and susceptibility to fungal infections. The study also showed that the order of receiving the dose of radiation and S16020 (20 days apart or simultaneously) did not affect their action [74,75].

\section{Mechanisms of Antitumor Activity of Olivacine and Olivacine Derivative}

The mechanism of action and antitumor properties of olivacine (presented in Figure 3) are similar to ellipticine and rely on direct interaction-intercalation in DNA and topo II activity $[22,23]$. It should be emphasized that some olivacine derivatives, e.g., compound S16020, showed a broad spectrum of antitumor activity and greater activity than ellipticine derivatives and doxorubicin $[24,25]$.

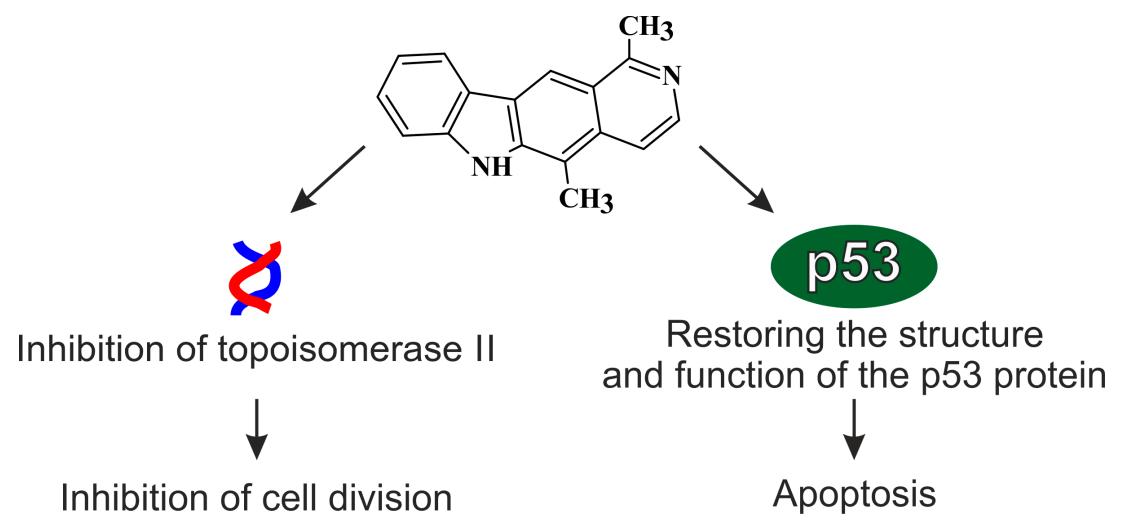

Figure 3. The mechanism of the antitumor action of olivacine.

\subsection{Inhibition of the Function of Topoisomerase II (Topo II)}

Previous studies indicate that olivacine derivatives bind to the topo II dissectible enzyme-DNA complex [71]. It is assumed that the stabilization of the cleavable complex "from the side" of the enzyme, i.e., drug interactions with the topo II complex, is more durable and effective, promising effective stabilization of the complex [76]. It has been shown that in addition to blocking topo II, olivacine derivatives also intercalate into DNA. Thus, the determination of the share of direct interactions of new derivatives with the nucleic acid and interactions with the topo II enzyme may help in understanding the mechanisms of genotoxic action of these compounds, especially in comparison with the standard topo II inhibitor that stabilizes the cleavable topo II-DNA complexes-etoposide, which it is a semi-synthetic derivative of podophyllotoxin [77].

\section{2. $p 53$ Protein}

A promising direction of research in recent years in experimental oncology involves attempts to restore the structure and function of the p53 protein, which heralds the development of new therapeutic strategies, increasing the effectiveness of anticancer therapy. This is an important way to influence the death of cells through apoptosis, which in neoplastic 
disease is disturbed. Olivacine derivatives affect both the normal p53 protein and the wild-p53 protein [26,27].

\section{Conclusions}

In this review, we have described the alkaloid olivacine and its derivatives. Olivacine 1 has been known for 60 years, but all its properties are still not known. We know that it has been used against malaria, has anticancer properties, and inhibits E. coli bacteria. Its 9methoxyolivacine derivative significantly inhibits the growth of Mycobacterium tuberculosis. Importantly, however, the olivacine derivatives show greater antitumor activity than doxorubicin and ellipticine. At the same time, they are less toxic than ellipticine and doxorubicin, which are currently used in cancer treatment. Based on in vitro and in vivo activity, it can be seen that derivatives with a methyl substituent in the N-6 position of the pyridine carbazole system have the best activity.

Interestingly, the derivatives that showed very good activity in in vitro tests did not translate into in vivo tests (compounds having a hydroxyl group in the C-9 position of the pyridocarbazole system). The best effect seems to be introducing a moiety in the C-9 position of the pyridocarbazole system, which in the body will hydrolyze to the $\mathrm{OH}$ group. Interestingly, olivacine derivatives show a stronger effect on the $\mathrm{p} 53$ protein than ellipticine, a protein responsible for DNA repair or cell apoptosis. Also of interest are olivacine derivatives $\mathbf{2 8}$ and $\mathbf{2 9}$, which are active under hypoxic conditions but are very weakly active under aerobic conditions. These compounds may be precursors to drugs that act on anaerobic neoplasms and will not act on healthy cells. It seems that research on new olivacine derivatives may contribute to the development of new effective anticancer drugs.

Author Contributions: Conceptualization, B.T.; data curation, B.T.; writing-original draft preparation, B.T. and B.W.; writing-review and editing, B.T. and B.W.; visualization, B.T. All authors have read and agreed to the published version of the manuscript.

Funding: This research received no external funding.

Institutional Review Board Statement: Not applicable.

Informed Consent Statement: Not applicable.

Data Availability Statement: Not applicable.

Conflicts of Interest: The authors declare no conflict of interest.

\section{References}

1. Goodwin, S.; Smith, A.F.; Horning, E.C. Alkaloids of Ochrosia elliptica Labill. J. Am. Chem. Soc. 1959, 81, 1903-1908. [CrossRef]

2. Schmutz, J.; Hunziker, F. Aspidosperma-alkaloids. 3. The alkaloids of Aspidosperma olivaceum M. Arg. Pharm. Acta Helv. 1958, 33, 341-347.

3. Mosher, C.W.; Crews, O.P.; Acton, E.M.; Goodman, L. Preparation and Antitumor Activity of Olivacine and Some New Analogs. J. Med. Chem. 1966, 9, 237-241. [CrossRef] [PubMed]

4. Dalton, L.; Demerac, S.; Elmes, B.; Loder, J.; Swan, J.; Teitei, T. Synthesis of the tumour-inhibitory alkaloids, ellipticine, 9methoxyellipticine, and related pyrido[4,3-b]carbazoles. Aust. J. Chem. 1967, 20, 2715. [CrossRef]

5. Kohn, K.W.; Waring, M.J.; Glaubiger, D.; Friedman, C.A. Intercalative binding of ellipticine to DNA. Cancer Res. 1975, 35, 71-76. [PubMed]

6. Chu, Y.; Hsu, M. ta Ellipticine increase the superhelical density of intracellular SV40 DNA by intercalation. Nucleic Acids Res. 1992, 20, 4033-4038. [CrossRef] [PubMed]

7. Stiborova, M.; Rupertova, M.; Schmeiser, H.H.; Frei, E. Molecular mechanisms of antineoplastic action of an anticancer drug ellipticine. Biomed. Pap. Med. Fac. Univ. Palacky. Olomouc. Czech. Repub. 2006, 150, 13-23. [CrossRef]

8. Monnot, M.; Mauffret, O.; Simon, V.; Lescot, E.; Psaume, B.; Saucier, J.M.; Charra, M.; Belehradek, J.; Fermandjian, S. DNA-drug recognition and effects on topoisomerase II-mediated cytotoxicity. A three-mode binding model for ellipticine derivatives. J. Biol. Chem. 1991, 266, 1820-1829. [CrossRef]

9. Fossé, P.; René, B.; Charra, M.; Paoletti, C.; Saucier, J.M. Stimulation of topoisomerase II-mediated DNA cleavage by ellipticine derivatives: Structure-activity relationship. Mol. Pharmacol. 1992, 42, 590-595.

10. Froelich-Ammon, S.J.; Patchan, M.W.; Osheroff, N.; Thompson, R.B. Topoisomerase II binds to ellipticine in the absence or presence of DNA: Chaeacterization of enzyme-drug interactions by fluorescence spectroscopy. J. Biol. Chem. 1995, 270, 14998-15004. [CrossRef] 
11. Peng, Y.H.; Li, C.G.; Chen, L.H.; Sebti, S.; Chen, J.D. Rescue of mutant p53 transcription function by ellipticine. Oncogene 2003, 22, 4478-4487. [CrossRef] [PubMed]

12. Sugikawa, E.; Hosoi, T.; Yazaki, N.; Gamanuma, M.; Nakanishi, N.; Ohashi, M. Mutant p53 mediated induction of cell cycle arrest and apoptosis at G1 phase by 9-hydroxyellipticine. Anticancer Res. 1999, 19, 3099-3108.

13. Schwaller, M.A.; Allard, B.; Lescot, E.; Moreau, F. Protonophoric activity of ellipticine and isomers across the energy-transducing membrane of mitochondria. J. Biol. Chem. 1995, 270, 22709-22713. [CrossRef] [PubMed]

14. Hägg, M.; Berndtsson, M.; Mandic, A.; Zhou, R.; Shoshan, M.C.; Linder, S. Induction of endoplasmic reticulum stress by ellipticine plant alkaloids. Mol. Cancer Ther. 2004, 3, 489-497. [PubMed]

15. Stiborová, M.; Bieler, C.A.; Wiessler, M.; Frei, E. The anticancer agent ellipticine on activation by cytochrome P450 forms covalent DNA adducts. Biochem. Pharmacol. 2001, 62, 1675-1684. [CrossRef]

16. Frei, E.; Bieler, C.A.; Arlt, V.M.; Wiessler, M.; Stiborová, M. Covalent binding of the anticancer drug ellipticine to DNA in V79 cells transfected with human cytochrome P450 enzymes. Biochem. Pharmacol. 2002, 64, 289-295. [CrossRef]

17. Stiborová, M.; Stiborová-Rupertová, M.; Bořek-Dohalská, L.; Wiessler, M.; Frei, E. Rat microsomes activating the anticancer drug ellipticine to species covalently binding to deoxyguanosine in DNA are a suitable model mimicking ellipticine bioactivation in humans. Chem. Res. Toxicol. 2003, 16, 38-47. [CrossRef]

18. Stiborová, M.; Sejbal, J.; Bořek-Dohalská, L.; Aimová, D.; Poljaková, J.; Forsterová, K.; Rupertová, M.; Wiesner, J.; Hudeček, J.; Wiessler, M.; et al. The anticancer drug ellipticine forms covalent DNA adducts, mediated by human cytochromes P450, through metabolism to 13-hydroxyellipticine and ellipticine N2-oxide. Cancer Res. 2004, 64, 8374-8380. [CrossRef]

19. Stiborová, M.; Breuer, A.; Aimová, D.; Stiborová-Rupertová, M.; Wiessler, M.; Frei, E. DNA adduct formation by the anticancer drug ellipticine in rats determined by 32P postlabeling. Int. J. Cancer 2003, 107, 885-890. [CrossRef]

20. Kotrbová, V.; Aimová, D.; Brezinová, A.; Janouchová, K.; Poljaková, J.; Frei, E.; Stiborová, M. Cytochromes P450 reconstituted with NADPH: P450 reductase mimic the activating and detoxicating metabolism of the anticancer drug ellipticine in microsomes. Neuro Endocrinol. Lett. 2006, 27 (Suppl. 2), 18-22.

21. Aimová, D.; Svobodová, L.; Kotrbová, V.; Mrázová, B.; Hodek, P.; Hudeček, J.; Václavíková, R.; Frei, E.; Stiborová, M. The anticancer drug ellipticine is a potent inducer of rat cytochromes P450 1A1 and 1A2, thereby modulating its own metabolism. Drug Metab. Dispos. 2007, 35, 1926-1934. [CrossRef]

22. Malonne, H.; Atassi, G. DNA topoisomerase targeting drugs: Mechanisms of action and perspectives. Anticancer Drugs 1997, 8 , 811-822. [CrossRef]

23. Le Mée, S.; Pierré, A.; Markovits, J.; Atassi, G.; Jacquemin-Sablon, A.; Saucier, J.M. S16020-2, a new highly cytotoxic antitumor olivacine derivative: DNA interaction and DNA topoisomerase II inhibition. Mol. Pharmacol. 1998, 53, 213-220. [CrossRef]

24. Haider, N.; Sotelo, E. 1,5-dimethyl-6H-pyridazino[4,5-b]carbazole, a 3-aza bioisoster of the antitumor alkaloid olivacine. Chem. Pharm. Bull. 2002, 50, 1479-1483. [CrossRef]

25. Pichard-Garcia, L.; Weaver, R.J.; Eckett, N.; Scarfe, G.; Fabre, J.-M.; Lucas, C.; Maurel, P. The olivacine derivative S 16020 (9-hydroxy-5,6-dimethyl-N-[2-(dimethylamino)ethyl)-6H-pyrido(4,3-b)-carbazole-1-carboxamide) induces CYP1A and its own metabolism in human hepatocytes in primary culture. Drug Metab. Dispos. 2004, 32, 80-88. [CrossRef]

26. Piasny, J.; Wiatrak, B.; Dobosz, A.; Tylińska, B.; Gębarowski, T. Antitumor Activity of New Olivacine Derivatives. Molecules 2020, 25, 2512. [CrossRef]

27. Gębarowski, T.; Wiatrak, B.; Gębczak, K.; Tylińska, B.; Gąsiorowski, K. Effect of new olivacine derivatives on p53 protein level. Pharmacol. Rep. 2020, 72, 214-224. [CrossRef]

28. Walderley, M.G.L.; Shepherd, G.J.; Melhem, T.S.; Giulietti, A.M. Flora Fanerogâmica do Estado de São Paulo 4; Instituto de Botânica: São Paulo, Brazil, 2005.

29. Krentkowski, F.L.; Duarte, M.R. Morpho-anatomical analysis of Aspidosperma olivaceum and A. polyneuron, Apocynaceae. Rev. Bras. Farmacogn. 2012, 22, 937-945. [CrossRef]

30. Frausin, G.; de Freitas Hidalgo, A.; Lima, R.B.S.; Kinupp, V.F.; Ming, L.C.; Pohlit, A.M.; Milliken, W. An ethnobotanical study of anti-malarial plants among indigenous people on the upper Negro River in the Brazilian Amazon. J. Ethnopharmacol. 2015, 174, 238-252. [CrossRef] [PubMed]

31. Dolabela, M.F.; Oliveira, S.G.; Peres, J.M.; Nascimento, J.M.S.; Póvoa, M.M.; Oliveira, A.B. In vitro antimalarial activity of six Aspidosperma species from the state of Minas Gerais (Brazil). An. Acad. Bras. Cienc. 2012, 84, 899-910. [CrossRef] [PubMed]

32. Rocha e Silva, L.F.; Montoia, A.; Amorim, R.C.N.; Melo, M.R.; Henrique, M.C.; Nunomura, S.M.; Costa, M.R.F.; Andrade Neto, V.F.; Costa, D.S.; Dantas, G.; et al. Comparative in vitro and in vivo antimalarial activity of the indole alkaloids ellipticine, olivacine, cryptolepine and a synthetic cryptolepine analog. Phytomedicine 2012, 20,71-76. [CrossRef]

33. Touaty, P.; Simon, M. Effects of olivacine on the metabolism of proteins and nucleic acids in Escherichia coli. Biochim. Biophys. Acta 1982, 697, 313-321. [CrossRef]

34. Tylińska, B.; Redzicka, A. Synthesis of olivacine. Wiadomości Chem. 2015, 69, 11-12.

35. Maftouh, M.; Besselievre, R.; Monsarrat, B.; Lesca, P.; Meunier, B.; Husson, H.P.; Paoletti, C. Synthesis and cytotoxic activity of hydroxylated derivatives of olivacine in relation with their biotransformation. J. Med. Chem. 1985, 28, 708-714. [CrossRef]

36. Rivalle, C.; Wendling, F.; Tambourin, P.; Lhoste, J.M.; Bisagni, E.; Chermann, J.C. Antitumor amino-substituted pyrido[3', $\left.4^{\prime}: 4,5\right]$ pyrrolo[2,3-g]isoquinolines and pyrido[4,3-b]carbazole derivatives: Synthesis and evaluation of compounds resulting from new side chain and heterocycle modifications. J. Med. Chem. 1983, 26, 181-185. [CrossRef] 
37. Ducrocq, C.; Wendling, F.; Chermann, J.C.; Tourbez-Perrin, M.; Rivalle, C.; Tambourin, P.; Pochon, F.; Bisagni, E. Structure-activity relationship in a series of newly synthesized 1-amino-substituted ellipticine derivatives. J. Med. Chem. 1980, 23, 1212-1216. [CrossRef] [PubMed]

38. Jasztold-Howorko, R.; Bisagni, E.; Chermann, J.-C. Synthesis and biological activity of N-(N,N-dialkylaminoalkyl)-1-aminomethyl5-methyl-9-methoxy(6H)pyrido[4,3-b]carbazoles (ellipticines). Eur. J. Med. Chem. Chim. Ther. 1984, 19, 541-544.

39. Guillonneau, C.; Pierré, A.; Charton, Y.; Guilbaud, N.; Kraus-Berthier, L.; Léonce, S.; Michel, A.; Bisagni, E.; Atassi, G. Synthesis of 9-O-substituted derivatives of 9-hydroxy-5, 6-dimethyl-6H-pyrido[4,3-b]carbazole-1-carboxylic acid (2(dimethylamino)ethyl)amide and their 10- and 11-methyl analogues with improved antitumor activity. J. Med. Chem. 1999, 42, 2191-2203. [CrossRef]

40. Jasztold-Howorko, R.; Landras, C.; Pierré, A.; Atassi, G.; Guilbaud, N.; Kraus-Berthier, L.; Léonce, S.; Rolland, Y.; Prost, J.F.; Bisagni, E. Synthesis and evaluation of 9-hydroxy-5-methyl-(and 5,6-dimethyl)-6H-pyrido[4,3-b]carbazole-1$\mathrm{N}$-[(dialkylamino)alkyl]carboxamides, a new promising series of antitumor olivacine derivatives. J. Med. Chem. 1994, 37, 2445-2452. [CrossRef]

41. Landras, C.; Jasztold-Howorko, R.; Pierré, A.; Léonce, S.; Guilbaud, N.; Kraus-Berthier, L.; Guillonneau, C.; Rolland, Y.; Atassi, G.; Bisagni, E. Synthesis and biological evaluation of 6-(9-hydroxy-5-methyl (and 5,6-dimethyl)-6H-pyrido[4,3-b]carbazol1-yl)picolinic amides as new olivacine derivatives. Chem. Pharm. Bull. (Tokyo) 1996, 44, 2169-2172. [CrossRef] [PubMed]

42. Tylińska, B.; Jasztold-Howorko, R.; Kowalczewska, K.; Szczaurska-Nowak, K.; Gębarowski, T.; Wietrzyk, J. Design, synthesis and analysis of anticancer activity of new SAR-based S16020 derivatives. Acta Pol. Pharm.—Drug Res. 2018, 75, 1313-1320. [CrossRef]

43. Jasztold-Howorko, R.; Tylińska, B.; Biaduń, B.; Gebarowski, T.; Gasiorowski, K. New pyridocarbazole derivatives. Synthesis and their in vitro anticancer activity. Acta Pol. Pharm. 2013, 70, 823-832.

44. Guillonneau, C.; Nault, A.; Raimbaud, E.; Léonce, S.; Kraus-Berthier, L.; Pierré, A.; Goldstein, S. Cytotoxic and antitumoral properties in a series of new, ring D modified, olivacine analogues. Bioorg. Med. Chem. 2005, 13, 175-184. [CrossRef] [PubMed]

45. Tylińska, B.; Jasztold-Howorko, R.; Mastalarz, H.; Szczaurska-Nowak, K.; Materek, P.; Wietrzyk, J. Synthesis of new 1-phenyl-6Hpyrido[4,3-b]carbazole derivatives with potential cytostatic activity. Acta Pol. Pharm. 2011, 68, 31-37. [PubMed]

46. Tylińska, B.; Jasztold-Howorko, R.; Mastalarz, H.; Kłopotowska, D.; Filip, B.; Wietrzyk, J. Synthesis and structure-activity relationship analysis of new olivacine derivatives. Acta Pol. Pharm. 2010, 67, 495-502. [PubMed]

47. Jasztold-Howorko, R.; Pelczynska, M.; Nasulewicz, A.; Wietrzyk, J.; Opolski, A. Synthesis of 5,6-dimethyl-9-methoxy-1-phenyl6H-pyrido[4,3-b]carbazole derivatives and their cytotoxic activity. Arch. Pharm. (Weinheim) 2005, 338, 556-561. [CrossRef]

48. Jasztold-Howorko, R.; Croisy, A.; Carrez, D.; Jaroszewicz, I.; Nasulewicz, A.; Pełczyńska, M.; Opolski, A. Synthesis, structure, and cytostatic properties of new olivacine derivatives. Arch. Pharm. (Weinheim) 2004, 337, 599-604. [CrossRef]

49. Jasztold-Howorko, R.; Doroszkiewicz, W.; Bugla-Płoskońska, G.; Croisy, A.; Carrez, D. The synthesis and biological properties of a 1-(2-methylpyridin-4-yl) olivacine derivative. Sci. Pharm. 2005, 73, 101-112. [CrossRef]

50. Jasztold-Howorko, R.; Croisy, A.; Carrez, D. New 1-substituted 9-hydroxy-5,6-dimethyl-6H-pyrido [4,3-b]carbazole derivatives and their cytotoxicity. Acta Pol. Pharm. 2005, 62, 265-270.

51. Tylińska, B.; Ryng, S.; Gębarowski, T.; Gąsiorowski, K. Hypoxia- selective cytoxicity of olivacine analogues. Synthesis and biological screening. Acta Pol. Pharm. Drug Res. 2017, 74, 1753-1759.

52. Schmidt, U.; Theumer, G.; Jäger, A.; Kataeva, O.; Wan, B.; Franzblau, S.; Knölker, H.-J. Synthesis and Activity against Mycobacterium tuberculosis of Olivacine and Oxygenated Derivatives. Molecules 2018, 23, 1402. [CrossRef] [PubMed]

53. Vilarem, M.J.; Charcosset, J.Y.; Primaux, F.; Gras, M.P.; Calvo, F.; Larsen, C.J. Differential effects of ellipticine and aza-analogue derivatives on cell cycle progression and survival of BALB/c 3 T3 cells released from serum starvation or thymidine double block. Cancer Res. 1985, 45, 3906-3911. [PubMed]

54. Bisagni, E.; Hung, N.C. Premiere synthese de methyl-4-5h- pyrido $\left[3^{\prime}, 4^{\prime}: 4,5\right]$ pyrrolo $[3,2-c] p y r i d i n e s$, analogues tricycliques des aza-9 ellipticines. Tetrahedron 1986, 42, 2311-2318. [CrossRef]

55. Vilarem, M.J.; Riou, J.F.; Multon, E.; Gras, M.P.; Larsen, C.J. The in vitro involvement of topoisomerase II in the activity of azaellipticine analogues is not correlated with drug activity on isolated nuclei. Biochem. Pharmacol. 1986, 35, 2087-2095. [CrossRef]

56. Awada, A.; Giacchetti, S.; Gerard, B.; Eftekhary, P.; Lucas, C.; de Valeriola, D.; Poullain, M.G.; Soudon, J.; Dosquet, C.; Brillanceau, M.-H.; et al. Clinical phase I and pharmacokinetic study of S 16020, a new olivacine derivative: Report on three infusion schedules. Ann. Oncol. 2002, 13, 1925-1934. [CrossRef] [PubMed]

57. Paoletti, C.; Le Pecq, J.B.; Dat-Xuong, N.; Juret, P.; Garnier, H.; Amiel, J.L.; Rouesse, J. Antitumor activity, pharmacology, and toxicity of ellipticines, ellipticinium, and 9-hydroxy derivatives: Preliminary clinical trials of 2-methyl-9-hydroxy ellipticinium (NSC 264-137). Recent Results Cancer Res. 1980, 74, 107-123. [CrossRef]

58. Rouëssé, J.; Huertas, D.; Sancho-Garnier, H.; Le Chevalier, T.; Amiel, J.L.; Brulé, G.; Tursz, T.; Mondésir, J.M. 2 N methyl 9 hydroxy-ellipticine in treatment of metastatic breast cancers. Bull. Cancer 1981, 68, 437-441.

59. Clarysse, A.; Brugarolas, A.; Siegenthaler, P.; Abele, R.; Cavalli, F.; de Jager, R.; Renard, G.; Rozencweig, M.; Hansen, H.H. Phase II study of 9-hydroxy-2N-methylellipticinium acetate. Eur. J. Cancer Clin. Oncol. 1984, 20, 243-247. [CrossRef]

60. Khayat, D.; Borel, C.; Azab, M.; Paraisot, D.; Malaurie, E.; Bouloux, C.; Weil, M. Phase I study of Datelliptium chloride, hydrochloride given by 24-h continuous intravenous infusion. Cancer Chemother. Pharmacol. 1992, 30, 226-228. [CrossRef]

61. Ohashi, M.; Oki, T. Overview oncologic, endocrine \& metabolic: Oncologic, endocrine \& metabolic: Ellipticine and related anti-cancer agents. Expert Opin. Ther. Pat. 1996, 6, 1285-1294. [CrossRef] 
62. Kattan, J.; Durand, M.; Droz, J.P.; Mahjoubi, M.; Marino, J.P.; Azab, M. Phase I study of retelliptine dihydrochloride (SR 95325 B) using a single two-hour intravenous infusion schedule. Am. J. Clin. Oncol. 1994, 17, 242-245. [CrossRef]

63. Auclair, C.; Paoletti, C. Bioactivation of the antitumor drugs 9-hydroxyellipticine and derivatives by a peroxidase-hydrogen peroxide system. J. Med. Chem. 1981, 24, 289-295. [CrossRef] [PubMed]

64. Guilbaud, N.; Kraus-Berthier, L.; Saint-Dizier, D.; Rouillon, M.H.; Jan, M.; Burbridge, M.; Visalli, M.; Bisagni, E.; Pierré, A.; Atassi, G. In vivo antitumor activity of S 16020-2, a new olivacine derivative. Cancer Chemother. Pharmacol. 1996, 38, 513-521. [CrossRef]

65. Léonce, S.; Perez, V.; Casabianca-Pignede, M.R.; Anstett, M.; Bisagni, E.; Pierré, A.; Atassi, G. In vitro cytotoxicity of S16020-2, a new olivacine derivative. Investig. New Drugs 1996, 14, 169-180. [CrossRef] [PubMed]

66. Guilbaud, N.; Kraus-Berthier, L.; Saint-Dizier, D.; Rouillon, M.H.; Jan, M.; Burbridge, M.; Pierré, A.; Atassi, G. Antitumor activity of S 16020-2 in two orthotopic models of lung cancer. Anticancer Drugs 1997, 8, 276-282. [CrossRef]

67. Kraus-Berthier, L.; Guilbaud, N.; Jan, M.; Saint-Dizier, D.; Rouillon, M.H.; Burbridge, M.F.; Pierré, A.; Atassi, G. Experimental antitumour activity of S 16020-2 in a panel of human tumours. Eur. J. Cancer 1997, 33, 1881-1887. [CrossRef]

68. Giacchetti, S.; Cornez, N.; Eftekhari, P.; Awada, A.; Cuvier, C.; Bleiberg, H.; Hidvegi, E.; Berger, E.; Gerard, B.; Giroux, B.; et al. Phase I clinical trial of the olivacine S16020. Proc. Am. Assoc. Cancer Res. 1998, 39, 324.

69. Vassal, G.; Merlin, J.-L.; Terrier-Lacombe, M.-J.; Grill, J.; Parker, F.; Sainte-Rose, C.; Aubert, G.; Morizet, J.; Sévenet, N.; Poullain, M.-G.; et al. In vivo antitumor activity of S16020, a topoisomerase II inhibitor, and doxorubicin against human brain tumor xenografts. Cancer Chemother. Pharmacol. 2003, 51, 385-394. [CrossRef] [PubMed]

70. Pivot, X.; Awada, A.; Gedouin, D.; Kerger, J.; Rolland, F.; Cupissol, D.; Caponigro, F.; Comella, G.; Lopez-Pousa, J.J.; Guardiola, E.; et al. Results of randomised phase II studies comparing S16020 with methotrexate in patients with recurrent head and neck cancer. Ann. Oncol. 2003, 14, 373-377. [CrossRef]

71. Malonne, H.; Farinelle, S.; Decaestecker, C.; Gordower, L.; Fontaine, J.; Chaminade, F.; Saucier, J.M.; Atassi, G.; Kiss, R. In vitro and in vivo pharmacological characterizations of the antitumor properties of two new olivacine derivatives, S16020-2 and S30972-1. Clin. Cancer Res. 2000, 6, 3774-3782. [PubMed]

72. Kraus-Berthier, L.; Guilbaud, N.; Léonce, S.; Parker, T.; Genissel, P.; Guillonneau, C.; Goldstein, S.; Atassi, G.; Pierré, A. Comparison of the pharmacological profile of an olivacine derivative and a potential prodrug. Cancer Chemother. Pharmacol. 2002, 50, 95-103. [CrossRef] [PubMed]

73. Shewach, D.S.; Lawrence, T.S. Radiosensitization of human solid tumor cell lines with gemcitabine. Semin. Oncol. 1996, $23,65-71$.

74. Maggiorella, L.; Frascogna, V.; Poullain, M.G.; Berlion, M.; Lucas, C.; Razy, S.D.; Eschwege, F.; Bourhis, J. The olivacine S16020 enhances the antitumor effect of ionizing radiation without increasing radio-induced mucositis. Clin. Cancer Res. 2001, 7, 2091-2095. [PubMed]

75. Boal, D.K.; Newburger, P.E.; Teele, R.L. Esophagitis induced by combined radiation and adriamycin. AJR. Am. J. Roentgenol. 1979, 132, 567-570. [CrossRef] [PubMed]

76. Burden, D.A.; Osheroff, N. Mechanism of action of eukaryotic topoisomerase II and drugs targeted to the enzyme. Biochim. Biophys. Acta 1998, 1400, 139-154. [CrossRef]

77. Montecucco, A.; Biamonti, G. Cellular response to etoposide treatment. Cancer Lett. 2007, 252, 9-18. [CrossRef] 